\title{
Implementasi Motor Servo MG996r Sebagai Robot Pemegang Batang Nosel Pada Sprayer Elektrik Berbasis Arduino Mega2560
}

\author{
Rusdiyanto ${ }^{1}$, Ibrahim $^{2}$, insani abdi bangsa ${ }^{3}$ \\ ${ }^{1}$ Jurusan Teknik Elektro Universitas Singaperbangsa Karawang, JL. HS. Robggo Waluyo, Peseurjaya, Kec. \\ Telukjambe Timur, Kabupaten Karawang, Jawa Barat 41362, e-mail : Rusdi.yanto121@studen.unsika.ac.id \\ ${ }^{2}$ Jurusan Teknik Elektro Universitas Singaperbangsa Karawang, JL. HS. Robggo Waluyo, Peseurjaya, Kec. \\ Telukjambe Timur, Kabupaten Karawang, Jawa Barat 41362, e-mail : Ibra.lammada@gmail.com \\ ${ }^{3}$ Jurusan Teknik Elektro Universitas Singaperbangsa Karawang, JL. HS. Robggo Waluyo, Peseurjaya, Kec. \\ Telukjambe Timur, Kabupaten Karawang, Jawa Barat 41362, e-mail : iabdibangsa@ft.unsika.ac.id
}

Received 23 maret 2021

Received in revised form 29 Juni 2021

Accepted 29 Juli 2021

Available online July 2021

\begin{abstract}
The sprayer is one of the equipments that is often used in agriculture, especially in rice plants to control pests and diseases. The use of the nozzle rod on the electric sprayer still uses hands resulting in the spray distance on the rice being not constant. To answer this problem, the researcher will create an innovative robotic hand holding the nozzle rod on an electric sprayer that will direct the nozzle rod constantly. Servo MG996r as a rectifier of the motion of the nozzle stem which will determine the distance and area of spraying on rice. To achieve maximum dispersion in rice with a 4:1 legowo system with a servo rod length of $50 \mathrm{~cm}$ and a spacing between rice of $25 \mathrm{~cm}$, the servo must move forward and backward at an angle of $110^{\circ}-180^{\circ}$ which can be seen on the LCD and the distance of the nozzle rod on the object can be up and down to $38 \mathrm{~cm}$ and up $24 \mathrm{~cm}$ from the starting position. The results obtained by the robotic hand holding the nose bridge can work optimally.
\end{abstract}

Keywords - robot, rice, sprayer

\begin{abstract}
ABSTRAK
Alat penyemprot (sprayer) merupakan salah satu peralatan yang sering digunakan di dunia pertanian terutama pada tanaman padi guna pengendalian hama dan penyakit. Penggunaan batang nosel pada sprayer elektrik masih menggunakan tangan mengakibatkan arah jarak semprot pada padi tidak konstan. Untuk menjawab masalah tersebut peneliti akan membuat inovasi robot tangan pemegang batang nosel pada sprayer elektrik yang akan mengarahkan batang nosel dengan konstan. Servo MG996r sebagai penyearah gerak batang nosel yang akan bergerak menentukan jarak dan luas penyemprotan pada padi. untuk mencapai maksimal luas penyemprotan pada padi sistem legowo 4:1 dengan panjang batang servo $50 \mathrm{~cm}$ dan jarak tanam antar padi $25 \mathrm{~cm}$ servo harus bergerak maju dan mundur di sudut $110^{\circ}-180^{\circ}$ yang bisa dilihat di LCD display dan untuk jarak batang nosel pada objek bisa naik turun sampai $38 \mathrm{~cm}$ dan naik $24 \mathrm{~cm}$ dari posisi awal. Hasil yang didapat robot tangan pemegang batang nosel dapat bekerja dengan optimal.
\end{abstract}

Received Mei 23, 2021; Revised Juni 29, 2021; Accepted Juli 29, 2021 
Kata kunci - robot , padi, sprayer

\section{PENDAHULUAN}

Perkembangan teknologi telah mempengaruhi kehidupan sehari-hari. Pengaruhnya adalah hampir semua kalangan tak luput terhadap penggunaan teknologi, dikarenakan teknologi memiliki kemampuan untuk meringankan pekerjaan si pengguna, baik dari efesien waktu maupun tenaga. di dunia pertanian mengalami perkembangan yang sangat pesat. Meningkatnya sumberdaya manusia yang begitu pesat di berbagai belahan dunia yang mengakibatkan sektor pertanian mengalami persaingan yang semakin ketat Produktivitas, mutu, efesiensi, dan kontinuitas yang selalu meningkat menjadikan salah satu ciri pertanian modern. Berbagai macam peralatan diciptakan untuk menciptakan kualitas dan kuantitas hasil pertanian agar memiliki daya saing yang bagus. Indonesia sebagai Negara yang sebagian besar penduduknya bermata pencaharian sebagai petani dituntut untuk dapat mengikuti perkembangan yang ada. Menurut data hasil penelitian yang dilakukan Badan Pusat Statistik (BPS) pada tahun 2020 luas lahan petani padi di indonesia mencapai 10.657.274,96 (ha) dengan hasil produksi mencapai 54.649.202,24 ton.

Seiring dengan berkembangnya teknologi, prinsip efesiensi dan efektivitas kerja sangat diutamakan. Berdaasarkan haltersebut, dalam pembangunan dan perekonomian nasional sector pertanian memiliki peran yang sangat penting terutama dalam pembangunan nasioanal. Hubungan antara sektor pertanian dan perindutrian yang saling membutuhkan membentuk suatu keterkaitan dalam pembuatan produk untuk diperdagangkan. Obat-obatan pembasmi hama padi, pupuk serta alat-alat pertanian sangat diperlukan bagi pertanian untuk meningkatkan produktivitas hasil panen.

Diindonesia terutama dipelosok-pelosok desa rata-rata untuk peralatan pertanian jarang adanya teknologi sistem otomasi. Sehingga perlu adanya pembelajaran, modifikasi serta pengembangan teknologi untuk dapat menciptakan peralatan yang dapat meningkatkan efesiensi dan efektivitas kerja petani. Sehingga dapat mempersingkat dan memperingan kerja petani serta meningkatkan hasil produktivitasnya. Salah satu alat yang digunakan oleh petani padi adalah alat penyemprot (sprayer). Sprayer merupakan sarana yang digunakan petani padi dalam rangka pemberantasan hama, pengendalian hamaserta pemberian nutrisi pada padi. Sprayer elektrik salah satu sprayer tipe gendong yang menggunakan aki sebagai energinya. Stik pengarah droplet merupakan alat yang digunakan sprayer elektrik untuk mengarahkan cairan droplet pestisida ataupun pupuk dari tengki ke padi. Sebagian besar pemakaian stik penarah droplet masih menggunakan sistem manual menggunakan tangan.

Berdasarkan permasalahan tersebut, peneliti akan menginovasi batang nosel pengarah droplet sprayer elektrik tipe gendong. Modifikasi yang menjadikan sprayer elektrik tipe gendong dalam pengarahan batang nosel keluarnya droplet menjadi sistem otomatis dengan membuat lengan robot pemegang batang nosel pengarah droplet. Dengan begitu akan menjawab kebutuhan dan masalah yang dihadapi petani padi. Sehingga dapat memberikan manfaat yang besar. Maanfaat yang didapat oleh petani padi yaitu lebih efesiensi waktu penyemprotan, dan mepermudah dalam pengarahan batang nosel, sehingga akan meningkatkan efesiensi kerja dan penghasilan petani padi.

\section{TINJAUAN PUSTAKA}

Muhammad nafis Rahman 2014 melakukan penelitian tentang modifikasi nosel pada sprayer gendong elektrik yang akan membandingkan antara tekanan yang keluar pada nosel sprayer manual dan sprayer elektrik. Hasil peneliti menyebutkan bahwa modifikasi nosel memiliki pengaruh yang cukup signifikan untuk mengurangi pergeseran titik semprot, dengan kecepatan angina sebesar $1.32 \mathrm{~m} / \mathrm{s}$ maka dapat mengurangi pergeseran droplet sepanjang $0.75 \mathrm{~m}$, kondisi ini akan semakin baik jika kecepatan angina yang dihasilkan blower pada nosel lebih besar.

Hari pangestu 2018 melakukan penelitian tentang kebutuhan daya, luas sebaran nozzle, waktu penyemprotan dan kapasitas alat pada sprayer knapsack dan sprayer elektrik. Hasil peneliti menyebutkan bahwa pompa DC sprayer elektrik yang digunakan lebih efektif dari pompa diafragma sprayer knapsack dari segi waktu dan tingkat stabil tekanan, daya yang dibituhkan alat sprayer tanpa beban ialah 8.82 watt, sedangkan rata-rata daya saat alat beroprasi ialah 23,01 watt, waktu semprot dari penuh hingga habis pada sprayer manual 28,2 menit sedangkan pada sprayer elektrik 14.8 menit, dan kapasitas lapang efektif pada sprayer manual ialah $0,054 \mathrm{ha} /$ jam sedangkan sprayer elektrik $0.125 \mathrm{ha} / \mathrm{jam}$.

\section{Implementasi Motor Servo MG996r Sebagai Robot Pemegang Batang Nosel Pada Sprayer Elektrik Berbasis Arduino Mega2560}



(online)

Tri bayu cokroyoso dipuro niti 2014 menurutnya sprayer merupakan alat pengendali hama yang berfungsi memecah cairan menjadi tetesan kecil (droplet) dan mendistribusikan secara merata pada objek yang dilidungi. Pada penelitian ini peneliti membuat model fisik sprayer elektrik bertujuan memanfaatkan energy matahari yang melimpah dan terbarukan guna pengendalian hama dan penyakit tanaman dengan konsep ramah lingkungan. Hasil dari penelitian ini adalah sebuah model penggerak pompa pneumatic spryer dengan selsurya $10 \mathrm{wp}$. Batrei $12 \mathrm{~V} 7.2$ Ah yang digunakan untuk penggerak pompa portable dengan tegangan kerja $12 \mathrm{~V}$, arus listrik 3-4 A dan tekanan kerja maksimal 17.5 bar. Dari uji coba diperoleh bawha semakin tinggi intesitas cahaya yang diterima panel suryamaka semakin singkat waktu pengisisan, maka arus yang masuk pada baterai bisa mencapa nilai 0.62 A dan tegangan $20.3 \mathrm{~V}$. debit keluar oleh nozzle pada tekanan $6-3 \mathrm{~kg} / \mathrm{cm} 2$ rata-rata $19-20 \mathrm{ml} / \mathrm{s}$. efesiensi pengisian baterai maksimal $13,14 \%$ pada intensitas sinar 89700 lux dan untuk efesiensi kerja pompa 23.65\%.

Berdasarkan tinjauan pustaka yang diperoleh adalah bukti dari perkembangan teknologi dibidang pertanian yang maju terutama pada alat pertanian sprayer pengendali hama dan penyakit pada tanaman. sprayer elektrik tipe gendong dengan bahan bakar yang ramah lingkungan menjadikan sprayer sebagai alat yang paling cocok untuk digunakan petani sebagai alat pengendali hama dan penyakit pada tanaman, dengan mengarahkan droplet secara merata pada objek yang akan disemprot maka efesiensi dan efektifitas penggunaan pada sprayer akan meningkat, dengan begitu menanamkan robot tangan untuk mengarahkan batang nosel secara otomatis bisa menjadikan jawaban untuk lebih meningkatkan efesiensi dan efektifitas dalam penyemprotan tanaman padi dengan sistem legowo 4:1.

\section{METODOLOGI PENELITIAN}

\subsection{Alur penelitian}

Penelitian ini dilakukan berdasarkan 5 tahapan, yang pertama studi kasus, kedua perancangan mekanisme robot lengan pengarah batang nosel, ketiga mengimplementasikan rancangan yang telah dibuat, keempat pelakukan pengujian terhadap robot lengan pengarah batang nosel, dan kelima pengambilan data serta pembahasan hasil rancangan.

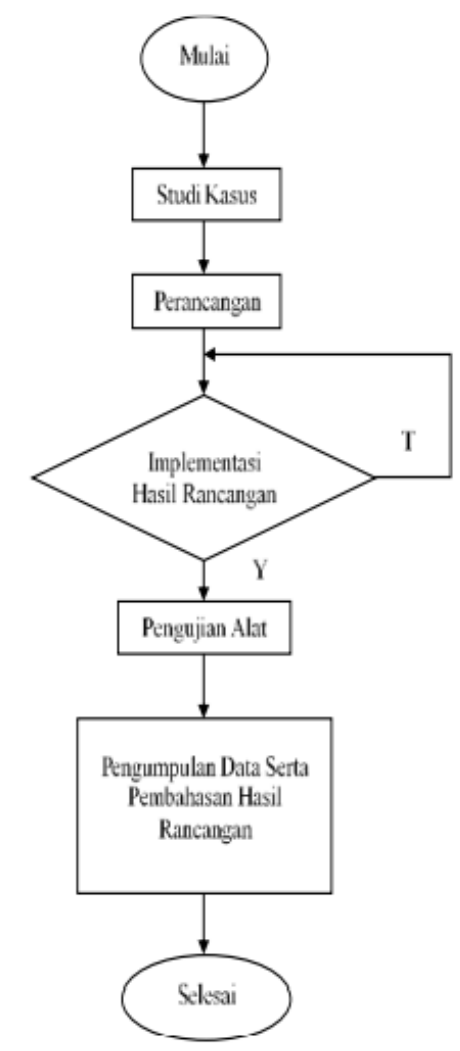

Gambar 3.1 Flowchart Metodologi Penelitian

\subsection{Perancangan}


3.2.1 Diagram model robot lengan pengarah stik kelua droplet

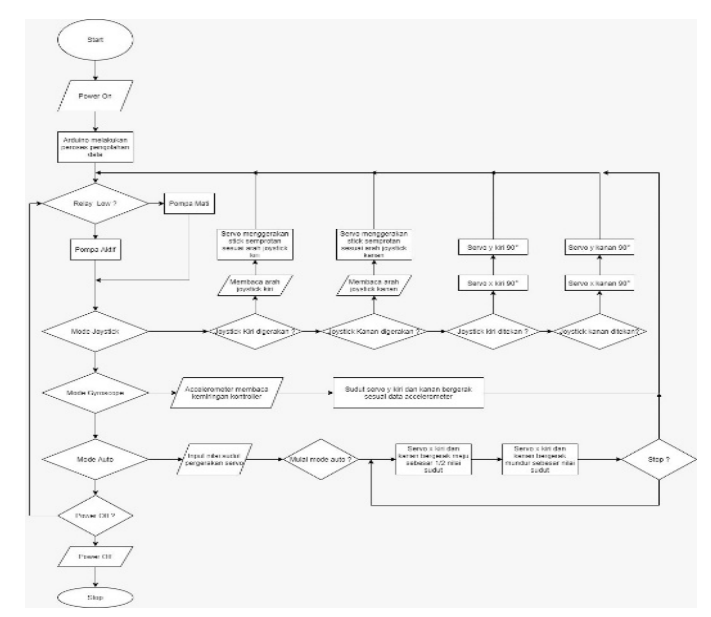

Gambar 3.2 Flowchar Sistem Robot Pemegang Batang Nosel

\subsubsection{Desain rancangan}

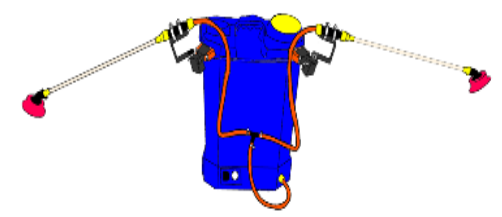

Gambar 3.3 Desain Rancangan Penanaman Robot Pemegang Batang Nosel

Gambar diatas menunjukan desain dari sistem robot lengan pengarah batang nosel. Dudukan motor servo dipasang dibagian belakang sprayer elektrik di kiri dan kanan dengan motor servo MG996r A dan servo MG996r C dibuat menyanggah dudukan motor servo MG996r B dan servo MG996r D . hal itu bertujuan untuk motor servo MG996r A dan servo MG996r C agar bisa menaikan dan menurunkan posisi batang nosel untuk menentukan jarak semprot. Dengan posisi motor servo MG996r B dan servo MG996r D yang dibuat disanggah motor servo MG996r A dan servo MG996r C bertujuan untuk mengarahkan batang nosel secara depan dan belakang yang nantinya akan menentukan luas jarak penyemprotan padi dengan sistem legowo 4:1 sesuai prinsip kerja sistem robot pemegang batang nosel.

\section{HASIL DAN PEMBAHASAN}

4.1 Skema Rangkaian Robot Pemegang Batang Nosel

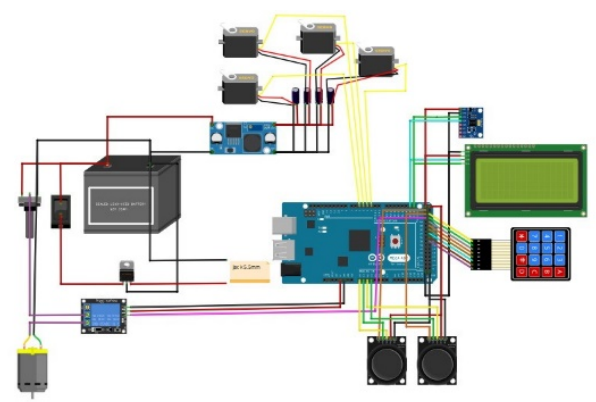

Gambar 4.1 Desain Rangkaian Robot Pemegang Batang Nosel

\section{Implementasi Motor Servo MG996r Sebagai Robot Pemegang Batang Nosel Pada Sprayer Elektrik Berbasis Arduino Mega2560}


(online)

\subsection{Implementasi robot robot pemegang stik kelur droplet otomatis}

4.2.1 Implementasi

4.2.1.1 Perangkat keras

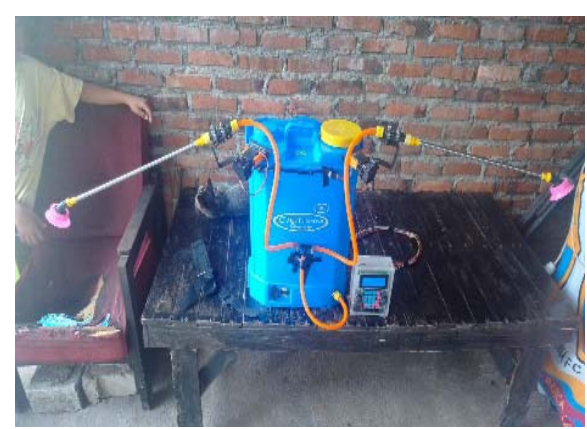

Gambar 4.2 Bentuk Fisik Robot Pemegang Batang Nosel

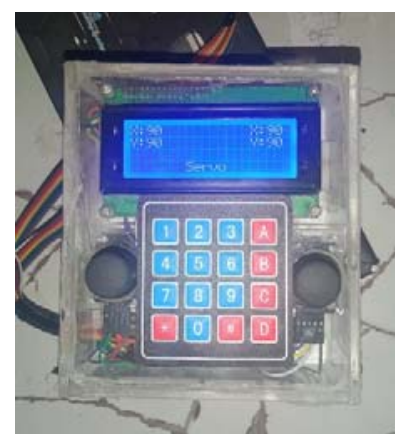

Gambar 4.3 Bentuk Fisik Remot Penentu Sudut Servo dan Monitoring Sudut Servo

\subsection{Tahap pengujia}

4.3.1 Pengujian motor servo MG996r A dan servo MG996r C

Pengujian pada motor servo MG996r A dan servo MG996r C dilakukan untuk mengetahui jarak antara ujung batang nosel dengan tanaman padi. Pada pengujian ini dilakukan dengan metode pengamatan pada sudut servo yang ditampilkan di LCD. Pengamatan ini dilakukan dengan dua kondisi yaitu saat sudut servo stanby dinaikan dan stanby diturunkan. Dari pengamatan didapatkan hasil sebagai berikut :

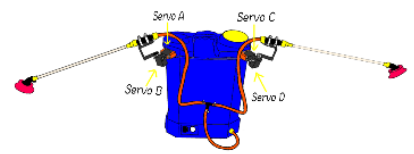

Gambar 4.4 Posisi Motor Servo A, B, C dan D

Motor servo MG996r A dan motor servo MG996r C dengan sudut yang bertolak belakang karna untuk menaikan jarak nosel ke padi sudut dari motor servo MG996r A harus lebih besar dari posisi awal servo MG996r A dan untuk menurunkan nosel sudut servo MG996r A harus lebih kecil dari posisi stanby servo MG996r A. Sedangkan untuk motor servo MG996r C kenaikan sudut dari posisi stanby akan menjadikan posisi batang nosel menjadi turun dan sebaliknya ketika sudut dari posisi awal diturunkan maka posisi nosel akan naik. Karena motor servo MG996r A dan motor servo MG996r C bertolak belakang menyebabkan keefesienan pada kedua batang nosel kiri dan kanan dalam menentukan jarak semprot pada padi sesua sistem yang dibuat. 
Jarak motor servo MG996r A dari posisi awal $90^{\circ}$ tinggi awal nosel $86 \mathrm{~cm}$ melaju ke atas mencapai tinggi maksimal 110 di sudut $160^{\circ}$ dan untuk sudut $170^{\circ}$ dan $180^{\circ}$ menjadi lebih rendah dikarnakan beban dari batang nosel mempengaruhi tinggi akhir dari sudut $170^{\circ}$ dan $180^{\circ}$ menjadikan sudut $160^{\circ}$ menjadi tinggi maksimal dari nosel. Sedangkan untuk jarak motor servo MG996r A dari posisi awal $90^{\circ}$ tinggi awal nosel $86 \mathrm{~cm}$ melaju ke bawah mencapai tinggi minimal $48 \mathrm{~cm}$ di sudut $10^{\circ}$ dan untuk sudut $0^{\circ}$ menjadi lebih tinggi dikarnakan posisi awal tidak lurus menjadikan batang nosel pada saat sudut $0^{\circ}$ menjadi naik.

Jarak motor servo MG996r C dari posisi stanby $90^{\circ}$ tinggi awal nosel $86 \mathrm{~cm}$ melaju ke atas mencapai tinggi maksimal 110 di sudut $20^{\circ}$ dan untuk sudut $10^{\circ}$ dan $0^{\circ}$ menjadi lebih rendah dikarnakan beban dari batang nosel mempengaruhi tinggi akhir dari sudut $10^{\circ}$ dan $0^{\circ}$ menjadikan sudut $10^{\circ}$ menjadi tinggi maksimal dari ujung batang nosel. Sedangkan untuk jarak motor servo MG996r C dari posisi stanby $90^{\circ}$ tinggi awal nosel $86 \mathrm{~cm}$ melaju ke bawah mencapai tinggi minimal $48 \mathrm{~cm}$ di sudut $170^{\circ}$ dan untuk sudut $180^{\circ}$ menjadi lebih tinggi dikarnakan posisi tidak lurus menjadikan batang nosel pada saat sudut $180^{\circ}$ menjadi naik.

Tabel 4.1 Hasil uji motor servo MG996r A dan motor servo MG996r C saat sudut awal dinaikan

\begin{tabular}{cccc}
\hline $\begin{array}{c}\text { Sudut servo stanby } \\
\text { dinaikan } 90^{\circ}-0^{\circ}\end{array}$ & $\begin{array}{c}\text { Tinggi awal nosel } \\
\text { ke padi }(\mathrm{cm})\end{array}$ & $\begin{array}{c}\text { Tinggi nosel kiri (servo } \\
\text { MG996 A) ke padi saat } \\
\text { sudut dinaikan }(\mathrm{cm})\end{array}$ & $\begin{array}{c}\text { Tinggi nosel kanan (servo } \\
\text { MG996 C) ke padi saat sudut } \\
\text { dinaikan }(\mathrm{cm})\end{array}$ \\
\hline $90^{\circ}$ & 86 & 86 & 86 \\
\hline $80^{\circ}$ & 86 & 91 & 82 \\
\hline $70^{\circ}$ & 86 & 97 & 75 \\
\hline $60^{\circ}$ & 86 & 101 & 70 \\
\hline $50^{\circ}$ & 86 & 105 & 65 \\
\hline $40^{\circ}$ & 86 & 108 & 60 \\
\hline $30^{\circ}$ & 86 & 109 & 54 \\
\hline $20^{\circ}$ & 86 & 110 & 51 \\
\hline $10^{\circ}$ & 86 & 109 & 50 \\
\hline $0^{0}$ & 86 & 108 & \\
\hline
\end{tabular}

Tabel 4.2 Hasil uji motor servo MG996r A dan motor servo MG996r C saat sudut awal diturunkan

\begin{tabular}{cccc}
\hline Sudut servo stanby & Tinggi awal nosel & Tinggi nosel kiri (servo & Tinggi nosel kanan (servo \\
dinaikan $90^{\circ}-0^{\circ}$ & ke padi $(\mathrm{cm})$ & MG996 A) ke padi saat & MG996 C) ke padi saat sudut \\
& & sudut diturunkan $(\mathrm{cm})$ & diturunkan $(\mathrm{cm})$
\end{tabular}

\begin{tabular}{llll}
\hline $90^{\circ}$ & 86 & 86 & 86 \\
\hline $80^{\circ}$ & 86 & 82 & 91 \\
\hline $70^{\circ}$ & 86 & 75 & 97 \\
\hline $60^{\circ}$ & 86 & 70 & 101 \\
\hline $50^{\circ}$ & 86 & 65 & 105 \\
\hline $40^{\circ}$ & 86 & 60 & 108 \\
\hline $30^{\circ}$ & 86 & 54 & 110 \\
\hline $20^{\circ}$ & 86 & 51 & 109 \\
\hline $10^{\circ}$ & 86 & 48 & \\
\hline
\end{tabular}

Implementasi Motor Servo MG996r Sebagai Robot Pemegang Batang Nosel Pada Sprayer Elektrik Berbasis Arduino Mega2560 


\begin{tabular}{llll}
$0^{0}$ & 86 & 50 & 108 \\
\hline
\end{tabular}

\subsubsection{Pengujian motor servo MG996r B dan servo MG996r D}

Pengujian pada motor servo MG996r B dan servo MG996r D dilakukan untuk mengetahui luas penyemprotan batang nosel dengan tanaman padi secara otomatis dan waktu gerak batang servo. Pada pengujian ini dilakukan dengan metode pengamatan pada sudut servo yang ditampilkan di LCD. Pengamatan ini dilakukan dengan kondisi saat sudut servo stanby lalu digerakan dengan menaikan sudut servo. Dari pengamatan didapatkan hasil sebagai berikut :

sudut dari motor servo MG996r B dan servo MG996r D bertolak belakang bisa dilihat saat servo gerak dari posisi awal ke maju servo MG996r B mengalami kenaikan sudut sedangkan servo MG996r $\mathrm{D}$ mengalami penurunan sudut, sedangkan pada servo bergerak dari posisi awal ke mundur servo MG996r B mengalami penurunan sudut sedangkan servo MG996r D kenaikan sudut. Karena motor servo MG996r B dan motor servo MG996r D bertolak belakang menyebabkan keefesienan pada kedua batang nosel kiri dan kanan dalam menentukan luas penyemprotan pada padi.

Pada sudut servo $20^{\circ}-70^{\circ}$ hanya bergerak maju disudut $100^{\circ}-125^{\circ}$ dan mundur $80^{\circ}-55^{\circ}$ dari sudut awal $90^{\circ}$ yang mengakibatkan luas gerak batang servo akan bergerak maju dan mundur hanya sampai $10^{\circ}-35^{\circ}$ akibatnya luas penyemprotan pada sistem legowo $4: 1$ hanya dapat menyemprot 1-2 padi saja karenanya tidak disarankan untuk memakai sudut $20^{\circ}-70^{\circ}$.

Pada sudut servo $80^{\circ}-100^{\circ}$ hanya bergerak maju disudut $130^{\circ}-140^{\circ}$ dan mundur $40^{\circ}-50^{\circ}$ dari sudut awal $90^{\circ}$ yang mengakibatkan luas gerak batang servo akan bergerak maju dan mundur hanya sampai $40^{\circ}-50^{\circ}$ akibatnya luas penyemprotan pada sistem legowo $4: 1$ hanya dapat menyemprot 1-3 padi saja karenanya tidak disarankan untuk memakai sudut $80^{\circ}-100^{\circ}$.

Pada sudut servo $110^{\circ}-180^{\circ}$ akan bergerak maju disudut $145^{\circ}-180^{\circ}$ dan mundur $45^{\circ}-0^{\circ}$ dari sudut awal $90^{\circ}$ yang mengakibatkan luas gerak batang servo akan bergerak maju dan mundur sampai $55^{\circ}-90^{\circ}$ akibatnya luas penyemprotan pada sistem legowo 4:1 dapat menyemprot 1-4 padi dan pada posisi sudut $110^{\circ}-180^{\circ}$ sangat disarankan digunakan.

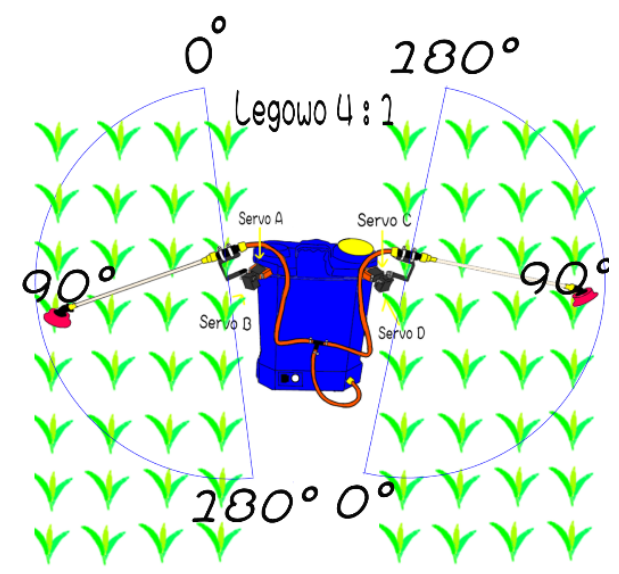

Gambar 4.5 Implementasi Lebar Jangkauan Batang Nosel Ke Padi

Tabel 4.3 Pengujian Motor Servo MG996r B Dan Servo MG996r D Dengan Menggerakan Batang Nosel Secara Otomatis Dengan Menaikan Sudut Servo

\begin{tabular}{|c|c|c|c|c|}
\hline Sudut Servo & $\begin{array}{l}\text { Sudut Servo } \\
\text { Awal }\end{array}$ & $\begin{array}{l}\text { Gerak Sudut Servo B } \\
\text { Saat Maju-Mundur }\end{array}$ & $\begin{array}{l}\text { Gerak Sudut Servo D } \\
\text { Saat Maju-Mundur }\end{array}$ & $\begin{array}{ll}\text { Sudut } & \text { Servo } \\
\text { Stop } & \end{array}$ \\
\hline $20^{\circ}$ & $90^{\circ}$ & $100^{\circ}-80^{\circ}$ & $80^{\circ}-100^{\circ}$ & $90^{\circ}$ \\
\hline $30^{\circ}$ & $90^{\circ}$ & $105^{\circ}-75^{\circ}$ & $75^{\circ}-105^{\circ}$ & $90^{\circ}$ \\
\hline $40^{\circ}$ & $90^{\circ}$ & $110^{\circ}-70^{\circ}$ & $70^{\circ}-110^{\circ}$ & $90^{\circ}$ \\
\hline $50^{\circ}$ & $90^{\circ}$ & $115^{\circ}-65^{\circ}$ & $65^{\circ}-115^{\circ}$ & $90^{\circ}$ \\
\hline
\end{tabular}


JURNAL ILMIAH ELEKTRONIKA DAN KOMPUTERp-ISSN : 1907-0012 (print)e-ISSN : 2714-5417 (online)

\begin{tabular}{|c|c|c|c|c|}
\hline $60^{\circ}$ & $90^{\circ}$ & $120^{\circ}-60^{\circ}$ & $60^{\circ}-120^{\circ}$ & $90^{\circ}$ \\
\hline $70^{\circ}$ & $90^{\circ}$ & $125^{\circ}-55^{\circ}$ & $55^{\circ}-125^{\circ}$ & $90^{\circ}$ \\
\hline $80^{\circ}$ & $90^{\circ}$ & $130^{\circ}-50^{\circ}$ & $50^{\circ}-130^{\circ}$ & $90^{\circ}$ \\
\hline $90^{\circ}$ & $90^{\circ}$ & $135^{\circ}-45^{\circ}$ & $45^{\circ}-135^{\circ}$ & $90^{\circ}$ \\
\hline $100^{\circ}$ & $90^{\circ}$ & $140^{\circ}-40^{\circ}$ & $40^{\circ}-140^{\circ}$ & $90^{\circ}$ \\
\hline $110^{\circ}$ & $90^{\circ}$ & $145^{\circ}-35^{\circ}$ & $35^{\circ}-145^{\circ}$ & $90^{\circ}$ \\
\hline $120^{\circ}$ & $90^{\circ}$ & $150^{\circ}-30^{\circ}$ & $30^{\circ}-150^{\circ}$ & $90^{\circ}$ \\
\hline $130^{\circ}$ & $90^{\circ}$ & $155^{\circ}-25^{\circ}$ & $25^{\circ}-155^{\circ}$ & $90^{\circ}$ \\
\hline $140^{\circ}$ & $90^{\circ}$ & $160^{\circ}-20^{\circ}$ & $20^{\circ}-160^{\circ}$ & $90^{\circ}$ \\
\hline $150^{\circ}$ & $90^{\circ}$ & $165^{\circ}-15^{\circ}$ & $15^{\circ}-165^{\circ}$ & $90^{\circ}$ \\
\hline $160^{\circ}$ & $90^{\circ}$ & $170^{\circ}-10^{\circ}$ & $10^{\circ}-170^{\circ}$ & $90^{\circ}$ \\
\hline $170^{\circ}$ & $90^{\circ}$ & $175^{\circ}-5^{\circ}$ & $5^{\circ}-175^{\circ}$ & $90^{\circ}$ \\
\hline $180^{\circ}$ & $90^{\circ}$ & $180^{\circ}-0^{\circ}$ & $0-180^{\circ}$ & $90^{\circ}$ \\
\hline
\end{tabular}

Dari hasil tabel diatas menunjukan sudut dari motor servo MG996r B dan servo MG996r D bertolak belakang bisa dilihat saat servo gerak dari posisi stanby ke maju servo MG996r B mengalami kenaikan sudut sedangkan servo MG996r D mengalami penurunan sudut, sedangkan pada servo bergerak dari stanby ke mundur servo MG996r B mengalami penurunan sudut sedangkan servo MG996r D kenaikan sudut. Karena motor servo MG996r B dan motor servo MG996r D bertolak belakang menyebabkan keefesienan pada kedua batang nosel kiri dan kanan dalam menentukan luas penyemprotan pada padi.

\section{KESIMPULAN}

Hasil dari implementasi robot tangan pengarah batang nosel sprayer elektrik berbasis arduino dengan tanaman padi sistem legowo dapat disimpulkan sebagai berikut :

1. Inovasi pada sprayer elektrik dengan menanamkan robot lengan pengarah batang nosel mampu mengarahkan batang nosel secara otomatis dengan menaikkan dan menurunkan sudut motor servo MG996r. Pada robot lengan pengarah batang nosel sudut servo kiri dan kanan bertolak belakang untuk menghasilkan konsistenitas dalam mengarahkan batang nosel

2. Pada servo MG996r A dan servo MG996r C dari posisi nosel $86 \mathrm{~cm}$ dapat diturunkan sampai $48 \mathrm{~cm}$ dan dari $86 \mathrm{~cm}$ dapat dinaikan sampai $110 \mathrm{~cm}$ jadi untuk turun menghasilkan $38 \mathrm{~cm}$ dari posisi awal dan untuk naik menghasilkan $24 \mathrm{~cm}$ dari posisi awal maka untuk keseluruhan dari posisi $0 \mathrm{~cm}$ dapat naik sampai $62 \mathrm{~cm}$. Pada servo MG996r B dan servo MG996r D dari posisi stanby di 90 derajat dapat bergerak maju dan mundur 180 derajat. Pada penyemprotan legowo lebih efektif menggunakan gerakan maju mundur dari 0-190,5-174, 10-170 dan 15-165 dikarenakan pada posisi tersebut luas penyemprotannya dapat mencapai semua baris dengan legowo $4: 1$

\section{DAFTAR PUSTAKA}

[1] Rahman, M,H \& Yamin, M. (2014). Modifikasi Nosel Pada Sistem Penyemprotan untuk Pengendalian Gulma Menggunakan Sprayer Gendong Elektrik. Institut Pertanian Bogor : jTEP JURNAL KETEKNIKAN PERTANIAN, 2(1), 39-46.

[2] Dharmawan, A ., I. \& Soekarno, S., II. (2020). Uji Distribusi Semprotan Sprayer Pestisida Dengan Patternator Berbasis Water Level Detector. Universitas jember : jurnal teknik pertanian lampung, 9(2), 8595.

[3] Pangestu, A. (2018). Modifikasi Sprayer Knapsack Menjadi Sprayer Popa Elektrik. (UNIVERSITAS SRIWIJAYA, 2018) Diakses

dari

\section{Implementasi Motor Servo MG996r Sebagai Robot Pemegang Batang Nosel Pada Sprayer Elektrik Berbasis Arduino Mega2560}


170

JURNAL ILMIAH ELEKTRONIKA DAN KOMPUTERp-ISSN : 1907-0012 (print)e-ISSN : 2714-5417 (online)

http://repository.unsri.ac.id/14064/1/RAMA_41201_05021381320032_00140476070005076105_01_front ref.pdf

[4] E \& S. Johan. (2017). Perancangan Alat Penyemprot Hama Tanaman Tipe Knapsack Berbasis Solar Panel 20 Wp. Banten : Motor Bakar : Jurnal Teknik Mesin, 1(1), 1-5.

[5] Rahman dkk. (2020). Rancang Bangun Prototype Manipulator Lengan Robot Menggunakan Motor Servo Berbasis Mikrikontroller. Makasar : ILTEK : Jurnal Teknologi, 15(1), 42-46.

[6] Isman dkk. (2016). Rancang Bangun Robot Tank Pada Sistem Deteksi Dan Pencarian Sumber Radiasi. Yogyakarta : UNS Surakarta, 216-222.

[7] Anak Kendali. Tutorial Arduino Membuat Kunci Digital Dengan Keypad Dan Servo. Diakses pada oktober 21 2020, dari https://www.anakkendali.com/tutorial-arduino-kunci-digital-krypad/

[8] Majid, M. (2016). Implementasi Arduino Mega 2560 Untuk Kontrol Miniatur Elevator Barang Otomatis. (Sarjana Pendidikan Program Studi Teknik Elektro, Universitas Negeri Semarang, 2016). Diakses dari https://lib.unnes.ac.id/27831/1/5301411060.pdf

[9] Afifah, H. (2015). Perancangan Alat Otomatis Penyemprot Hama Tanaman Padi Menggunakan Sensor Pir Dengan Sumber Pv Dan Baterai. (Proyek akhir, Universitas Jember, 2015). Diakses dari https://repository.unej.ac.id/bitstream/handle/123456789/73482/111903102023--

HILYATI\%20AFIFAH\%20Skripsi\%20fix-1-55.pdf?sequence=1\&isAllowed=y

[10] Priatmoko. A., I. Widodo. S., II. Salahudin. X., III. Analisis Tekanan Tangki Sprayer Dengan Variasi Besar Diameter Roda Dan Panjang Tuas Engkol Peluncur Dengan Menggunakan Satu Pompa Pada Sprayer Semi Otomatis.

[11] Warno dkk. Modifikasi dan pengujian sistem penyemprot padi dengan penambahan pompa elektrik. Jural riset sains dan teknologi, 4(1),1-6. 